\title{
Climate and the mfecane
}

AUTHORS:

Michael Garstang ${ }^{1,2}$

Anthony D. Coleman ${ }^{3}$

Matthew Therrell ${ }^{4}$

\section{AFFILIATIONS:}

${ }^{1}$ Department of Environmental

Sciences, University of Virginia

Charlottesville, Virginia, USA

${ }^{2}$ Simpson Weather Associates

Inc, Charlottesville, Virginia, USA

${ }^{3}$ Battlescenes Tours, Dundee,

South Africa

${ }^{4}$ Department of Geography,

University of Alabama,

Tuscaloosa, Alabama, USA

\section{CORRESPONDENCE TO:}

Michael Garstang

\section{EMAIL:}

mxg@swa.com

\section{POSTAL ADDRESS:}

Department of Environmental

Sciences, University of Virginia

PO Box 400123, Charlottesville,

VA 22904-4123, USA

DATES:

Received: 31 July 2013

Revised: 11 Nov. 2013

Accepted: 26 Nov. 2013

\section{KEYWORDS:}

southern African drought;

Natal history; coupled

ocean-atmosphere model;

tree-ring analysis; volcanism

\section{HOW TO CITE:}

Garstang M, Coleman AD, Therrell

$M$. Climate and the mfecane.

S Afr J Sci. 2014;110(5/6),

Art. \#2013-0239, 7 pages.

http://dx.doi.org/10.1590/

sajs.2014/20130239

(C) 2014. The Authors.

Published under a Creative

Commons Attribution Licence.
The mfecane is thought to be a massive upheaval and devastation of Nguni tribal chiefdoms in the second decade of the 19th century in what is now KwaZulu-Natal and the Eastern Cape of South Africa. Other historians have challenged this extreme interpretation suggesting that the use of the term mfecane be discontinued. We show that pervasive cycles of drought and cold periods in southern Africa are significantly amplified and extended by volcanic eruptions and that, in particular, the eruption of Tambora in 1815 triggered a prolonged and extreme climatic event which bears all of the characteristics ascribed to the mfecane. These findings are supported by a coupled ocean-atmosphere numerical model and by tree-ring rainfall and sea surface temperature analyses, suggesting that the term mfecane is an appropriate description of a singular climatic event.

\section{Introduction}

The term 'mfecane' has been used to describe a period of extreme privation, widespread famine, depopulation and displacement of people over a large area of southeast South Africa (Figure 1). Thought to have begun in the second decade of the 19th century, the phenomenon may have had antecedent contributing conditions and has been seen to have had extensive subsequent sociological and political repercussions potentially extending well into the 20th century.

The range of arguments on the mfecane advanced by southern African historians, cover the full spectrum from the ascription of late 20th century political decisions ${ }^{1}$ to the mfecane to abandoning the use of the term mfecane entirely. ${ }^{2}$

The purpose of this paper is not to enter into the complex broader issues implied by or ascribed to the mfecane but to explore, firstly, the inherent large-scale atmospheric controls on the climate of Africa, and, secondly, whether a specific geophysical event combined to precipitate such a human catastrophe. The resulting climatic anomaly led to conditions akin to what may have been described by the original meaning of the term in Xhosa (ukufaca) which is 'to be weak, emaciated by hunger', where the stress is upon 'famine'.'

Later use of the word mfecane, placing emphasis upon 'extreme famine', would then be entirely consistent with the environmental conditions which we will describe, irrespective of any subsequent consequences or interpretations.

Previous work has not addressed either of the above potential influences or employed such findings to interpret the full impact of environmental factors. Such evidence has not been called upon to identify among multiple causes, a set of circumstances which mark the event as distinct from others and provide a basis for the use of the term 'mfecane'.

We will first draw attention to the unique geographical position of the continent of Africa relative to global-scale circulations of the atmosphere. Two large-scale global circulations dominate the climate of the subtropical latitudes of Africa, inducing pervasive dryness and periodic, if not entirely predictable, decadal cycles of wet and dry conditions.

Secondly, we will examine the superimposition of the effects of the world's largest known volcanic eruption upon the larger-scale climatic periodicities as the critical contributing factor to the occurrence of extreme climatic conditions in the region of interest. Precipitation anomalies derived from a large-scale coupled ocean-atmosphere model will be interpreted for the time period and location.

Sea-surface temperatures (SST) in the adjacent Indian Ocean that coincide with dry and wet conditions derived from a tree-ring analysis confirm the model-predicted SST fields and precipitation anomalies.

\section{Large-scale atmospheric circulations over Africa}

The continent of Africa is centred upon the geographic equator, extending approximately 35 degrees of latitude polewards in each hemisphere (Figure 1). This apparently trivial geographical detail has in fact profound implications for the continent of Africa. Africa is indeed unique among the continents in its equator-centric location.

Two major atmospheric circulations - Hadley and Walker - are centred on the equator. The impact upon Africa of these two circulations, underemphasised in the literature, results first in curtailing and second in creating high variability in the rainfall over much of this continent outside of the equatorial region. About $75 \%$ of the continent receives less than $500 \mathrm{~mm}$ of rainfall per year: a direct product of the Hadley circulation. This meager rainfall is subject to high variability amplified by the periodic dry and wet decadal cycles induced by the Walker circulation.

\section{The Hadley circulation}

Surface wind fields driven by solar heating over the meteorological equator and the deflecting forces (Coriolis) of the rotating earth, result in the converging flow of the northeast and southeast trade winds. Figure 2a shows the Hadley circulation in its simplest but, for our purposes, most important form: mass convergence at the surface along the meteorological equator results in upward motion, cooling and condensation of the warm moist equatorial air, the formation of deep convective clouds and the production of the high rainfalls of the equatorial region approximately $15^{\circ} \mathrm{N}$ and $\mathrm{S}$ of the geographic equator. The descending poleward limbs of the Hadley cell, initially caused by high altitude $(15 \mathrm{~km})$ radiative cooling and increased density of the air, result in sinking, compression, 


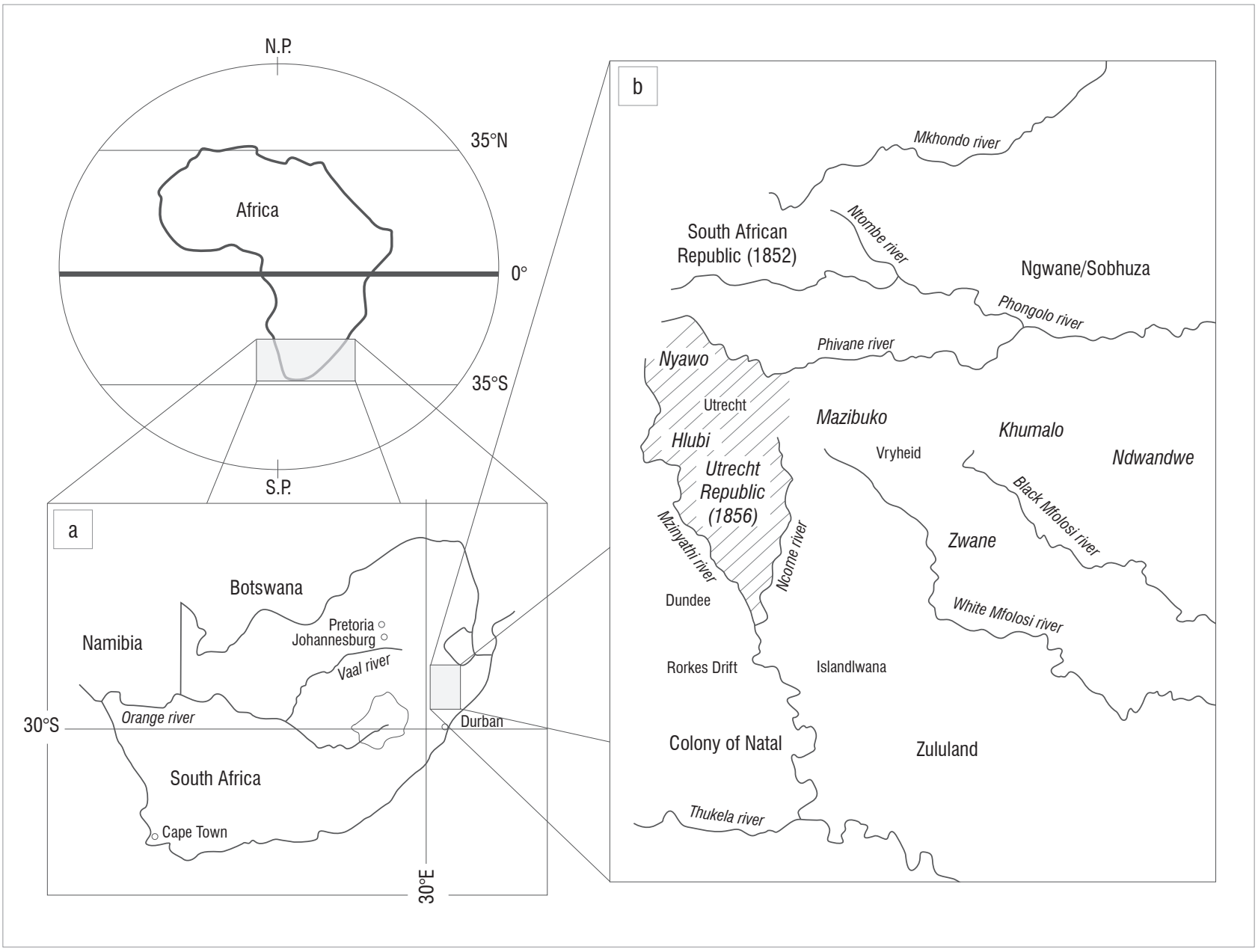

Figure 1: (a) The continent of Africa together with contemporary political boundaries and key cities, rivers and mountains of southern Africa and (b) the location of the Colony of Natal and Zululand together with tribal groups in the early to mid-19th century.

drying and warming of the atmosphere and the formation of the semipermanent subtropical anticyclones and the large hot deserts of Africa.

Figure $2 \mathrm{~b}$ shows the more complex manifestation of the Hadley circulation in the form of the Intertropical Convergence Zone (ITCZ) and the Zaire Air Boundary (ZAB) and their seasonal migrations. ${ }^{3}$ With the exception of the rain-producing regions of the convergence zones, the dominant effect of the Hadley circulation over Africa is a suppression of rainfall. The result is that much of Africa is dry, with an annual rainfall unable to support agriculture without supplemental (irrigation) water.

For rain to have been produced in the region of 19th-century Natal (Figure 1), the pervasive downward motions of the Hadley cell must have been countered by generation of upward motion. On the large scale, poleward excursions of the ITCZ can bring cyclonically circulating air in the form of easterly waves or equatorial vortices or even remnants of tropical cyclones (hurricanes) into the region. These phenomena are irregular and highly seasonal, occurring most often at the height of summer. Failing organised weather systems, daytime heating of the surface in summer, in the presence of moist air inflow from the Indian Ocean (warm Agulhas current), can develop afternoon thunderstorms and rain and could have made the coast of Natal wetter than the interior. Only rarely in the winter will frontal systems or low-pressure areas originating over the Southern Oceans, and reaching the Cape, penetrate into and beyond what was 19th-century Natal (Figure 1).

\section{The Walker circulation}

Extending around the world, centres of upward and downward motion form a chain of wet and dry regions located along the meteorological equator (Figure 3). ${ }^{4}$ Warming and cooling of the sea surface along this equatorial band, particularly in the far eastern Pacific Ocean, together with land masses create a longitudinal distribution in the centres of wet and dry conditions. When the waters of the far eastern Pacific warm, the cold upwelling off the coast of central America is replaced with warm surface water, nutrients from the depths are cut off and fishing ends. The fishermen of the region call this the El Niño. This warming of the surface water is the low phase of the Walker circulation shown in Figure 3a.

When the warm waters of the eastern Pacific retreat to be replaced by cold upwelling water, the La Niña has returned with the high phase of the Walker circulation (Figure 3b). The effects of the Pacific Ocean oscillations are transmitted around the globe through changes in the surface pressure fields as shown in Figure 3 . The surface pressure patterns result in alternating regions of wet (trough) and dry (ridge) conditions within the subtropics of the globe. Figure 3 shows that southern Africa would experience wet conditions under the high phase (La Niña) and dry conditions under the low phase (El Niño).

The east/west Walker circulation and the north/south Hadley circulation, are thus central to Africa. The periodic oscillations of trough (wet) and ridge (dry) pressure patterns extending into both hemispheres of Africa result in near decadal wet and dry periods that have been isolated for the summer rainfall regions of southern Africa. ${ }^{5}$ Other climatic forcing functions embedded within the adjacent Atlantic and Indian Oceans reinforce or interfere with the above climatic controls, increasing variability and reducing predictability. 


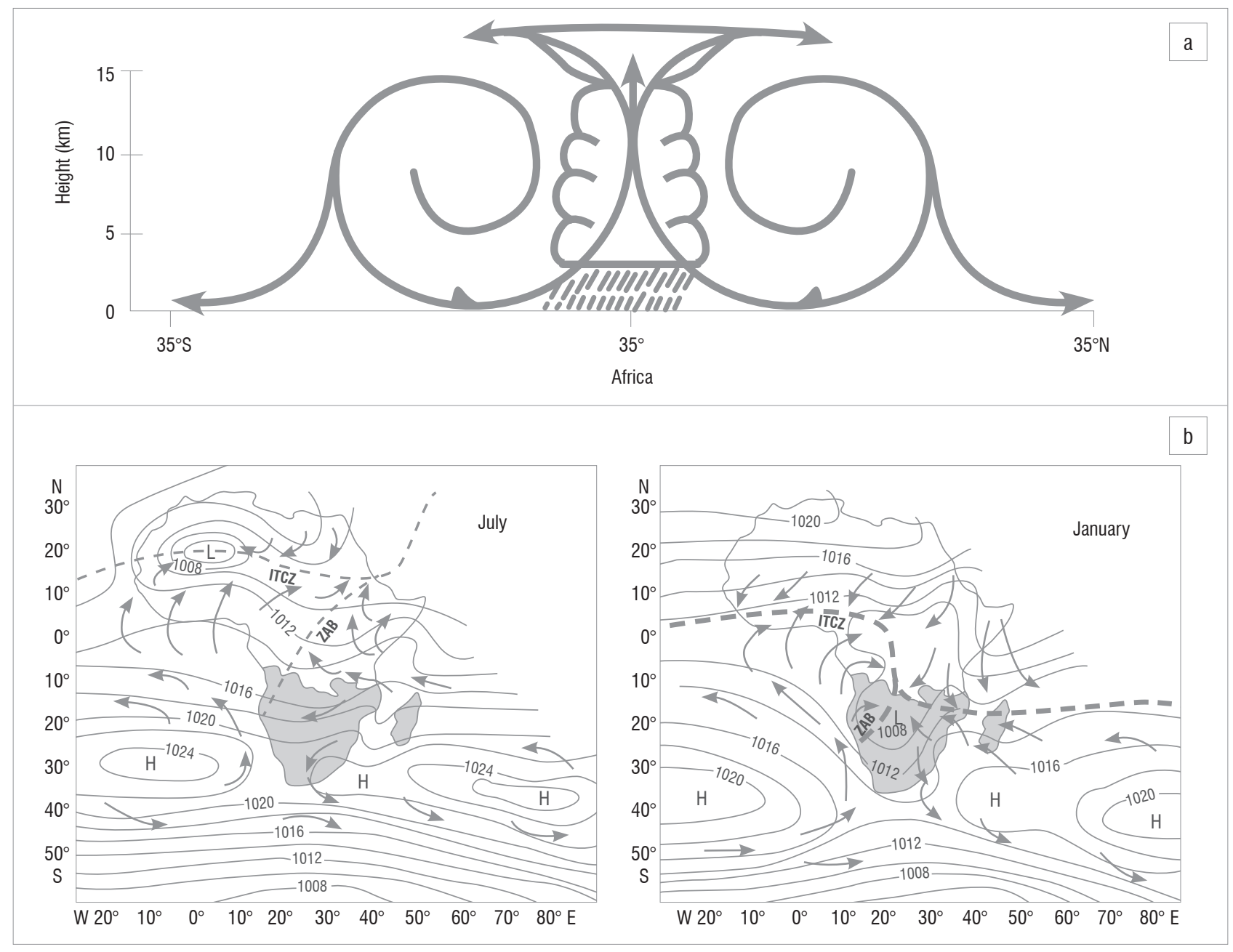

Source: Hobbs et al. ${ }^{3}$, p. 10

Figure 2: (a) Schematic of the Hadley circulation over Africa in the form of a vertical cross-section from the surface to $15 \mathrm{~km}$ extending along the north/ south length of Africa. Ascending air, cloud and rain dominate the equatorial region; descending air, drying and warming dominate the greater part of the continent. (b) The mean surface pressure $(\mathrm{mb})$ and wind (heavy arrows) fields for each season: July, northern hemisphere summer/ southern hemisphere winter, and January, northern hemisphere winter/southern hemisphere summer. The Intertropical Convergence Zone (ITCZ) and the Zaire Air Boundary (ZAB) are shown by heavy dashed lines.

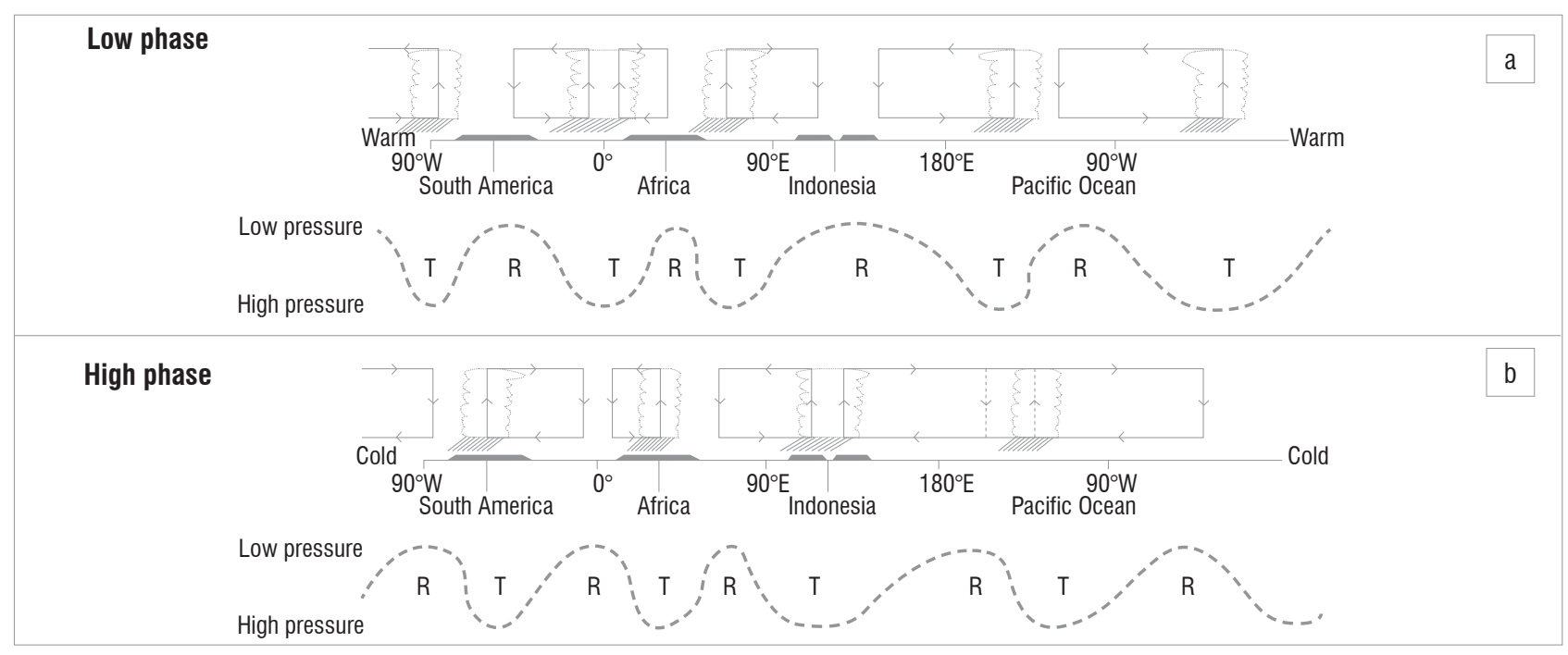

Source: Modified after Garstang and Fitzjarrald ${ }^{4}$

Figure 3: East to west globally encircling Walker circulation centred on the meteorological equator resulting in a trough (T)-ridge (R) oscillation in the surface pressure fields with accompanying wet (rain) and dry (drought) regions extending globally around the equator. The low phase (a) occurs when the far eastern Pacific warms (El Niño). The high phase (b) occurs when the far eastern Pacific cools (La Niña). 


\section{Sea-surface temperatures}

The El Niño-Southern Oscillation (ENSO) initiates changes in SST in the far eastern equatorial eastern Pacific, triggering the reversals in the Walker Circulation. ${ }^{6,7}$ Atlantic SSTs strongly influence the position of the ITCZ over Africa. ${ }^{8,9}$ Both observations and model studies suggest that the ITCZ moves away from cooler SSTs, potentially reducing the rainfall.

Figure $4 \mathrm{a}$, based on the 10 driest years according to tree-ring analysis in Zimbabwe from 1900 to 2000, shows colder ocean temperatures off the east coast of southern Africa compared to the 10 wettest years (Figure $4 \mathrm{~b}$ ), ${ }^{10}$ supporting the model results shown in Figure 5 of a 20\% decrease in annual precipitation.
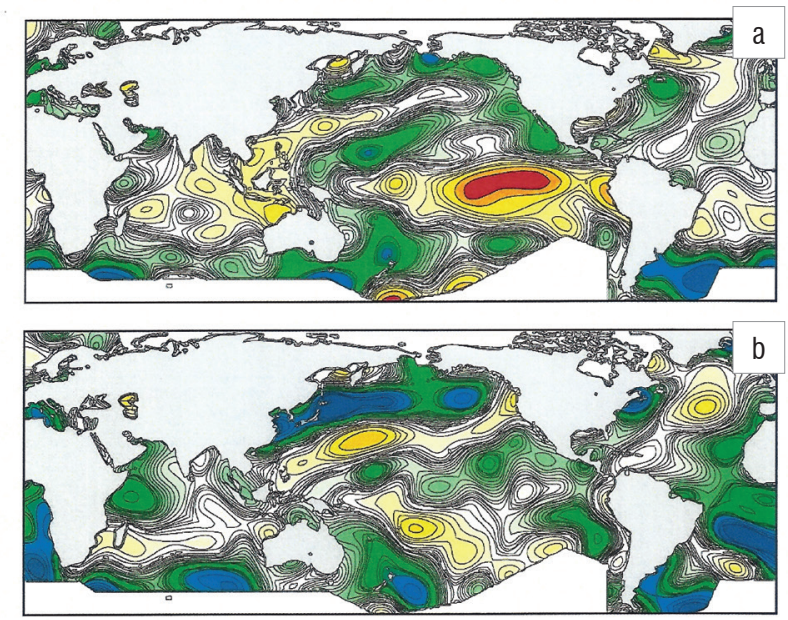

Composite temperature anomaly $\left({ }^{\circ} \mathrm{C}\right)$

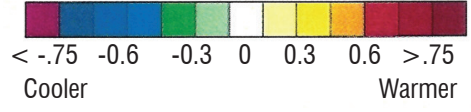

Figure 4: Composite sea-surface temperature anomalies for the (a) 10 driest and (b) 10 wettest years in the reconstructed rainfall record shown in Figure 6.

\section{Role of volcanism}

Numerous researchers, notably Lamb ${ }^{11}$ and Bryson and Goodman ${ }^{12}$, have pointed to volcanism as a major factor influencing climate, including SST and precipitation. More recently, Haywood et al. ${ }^{13}$ and others ${ }^{14,15}$ have modelled the climatic effects of large explosive volcanic eruptions. They concluded that large asymmetrical stratospheric aerosol loadings produced by the volcanoes and concentrated in the northern hemisphere result in droughts in the Sahel. Haywood et al. ${ }^{13}$, using the United Kingdom's Meteorological Office's coupled global atmosphereocean Hadley model (HadGEM), were able to show that the four driest Sahelian summers during the period 1900-2010 were preceded by substantial northern hemisphere volcanic eruptions.

We drew upon simulations conducted at the Hadley Centre to assess the impact of Tambora upon the climate of southeastern southern Africa. To do this, we used Hadley model simulations of volcanic eruptions whose optical depths most closely reflect conditions believed to have been present in the Tambora eruption. These optical depths are primarily controlled by the amount and height to which sulphur particles are injected into the atmosphere. These results are then used to predict the percentage change in the precipitation over southern Africa. The result (Figure 5) is conditioned by the fact that the volcanic explosivity index (VEI) of Tambora is two orders of magnitude greater than the VEI used for the simulation.

On 15 August 1815, Tambora - a volcano on the island of Simbawa in Indonesia - erupted, expelling some $140 \mathrm{gt}$ of magma. ${ }^{16}$ At position seven on the nine-point logarithmic VEI, Tambora is the largest known historical eruption. Located at $8.2^{\circ} \mathrm{S}$ latitude, $118^{\circ} \mathrm{E}$ longitude and lofting some $60 \mathrm{mt}$ of sulphur to an altitude of $45 \mathrm{~km}$, well into the stratosphere, this plume entered both the southern and northern hemispheres. Forming a global aerosol sulphate veil, reflecting short-wave radiation, there were pronounced climate repercussions in both hemispheres. Extending in the northern hemisphere as far north as Canada and Europe, 1816 was known as the 'year without a summer'. ${ }^{16}$ With the volume and character of the aerosols (high sulphur yield) above the stable barrier of the tropopause, it is estimated that the effect of this veil may have persisted for up to 5 years. The shortest growing season (less than $50 \%$ of normal) in southern Maine, New Hampshire and eastern Massachusetts between 1790 and 1840 was recorded for the year of $1816 .^{16}$

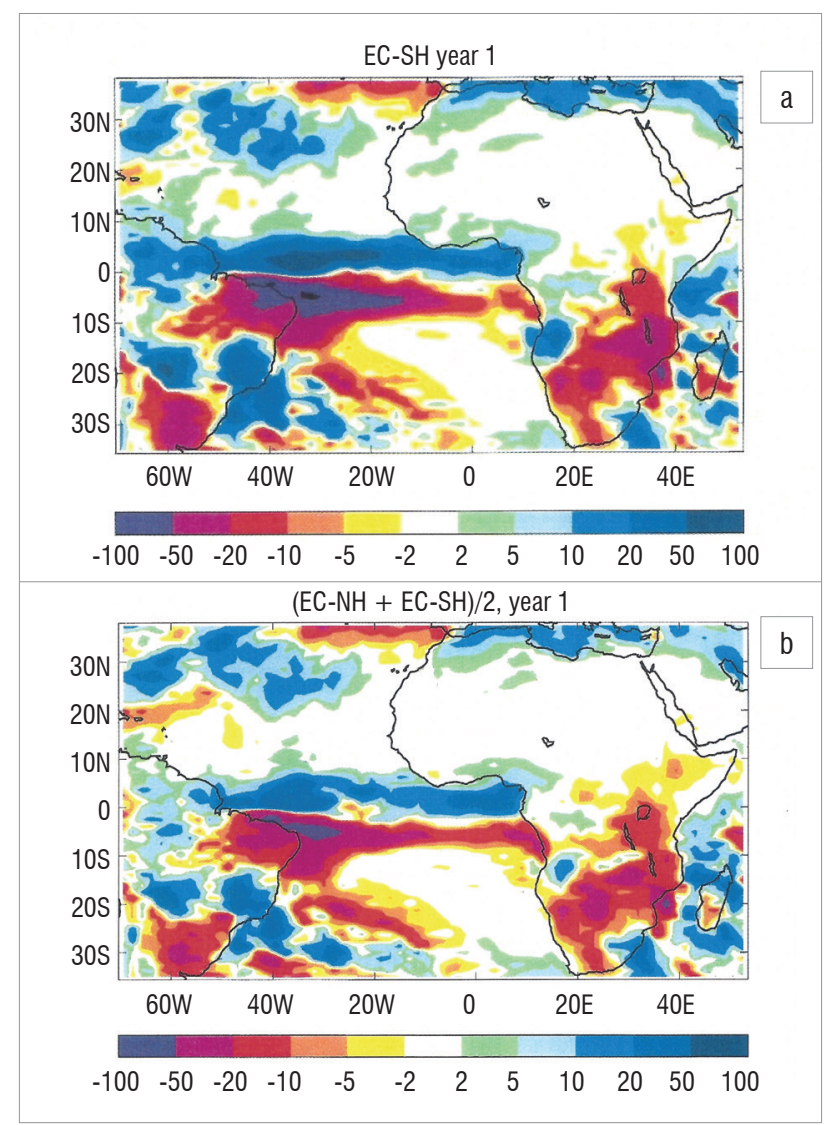

Figure 5: Model results from HadGEM for 1 year following an El Chichonscale eruption for (a) injection of the aerosol load into the southern hemisphere and (b) injection of the aerosol load into both hemispheres, showing the per cent of induced change in annual precipitation along the lower colour-coded bar.

Evidence of the impact of Tambora on the climate of the southern hemisphere following the 1815 eruption is much less detailed than that for the northern hemisphere. Grab and Nash ${ }^{17,18}$ used documentary evidence to study climatic variability during cold seasons in Lesotho between 1833 and 1900. They found, however, that the coldest period during the 19th century was the years following the 1815 eruption of Tambora. An unknown eruption preceded Tambora in 1809. ${ }^{19}$ While Grab and $\mathrm{Nash}^{17}$ were unable to document in detail the consequences of these two eruptions in southeastern southern Africa, they were able to describe the consequences of the eruptions of Amagura, also known as Toku, in the Fijian Island group $\left(18^{\circ} \mathrm{S}, 174^{\circ} \mathrm{W}\right)$, in June 1846 , and Krakatau $\left(6.1^{\circ} \mathrm{S}, 105.4^{\circ} \mathrm{E}\right)$ in August 1883 . Both of these eruptions were of lesser magnitude measured on the VEI than Tambora (Tambora 7, Amagura estimated at 4 and Krakatau 6). For the lowlands of Lesotho, Grab and Nash ${ }^{17}$ found three consecutive years of very severe winters and one additional year of severe winter from 1847 to 1850 following the eruption of Amagura. These winters resulted in extensive loss of human life and livestock. Despite the low sulphur yield of Krakatau, 
four consecutive years (1884-1887) of severe winters and early frosts followed that eruption.

The Hadley Centre's coupled atmosphere-ocean model results for a volcano the size of El Chichon, which injected 7-12 $\mathrm{MtSO}_{2}$ into the stratosphere, were then used to estimate the impact upon the precipitation of southern Africa. This volcano has been estimated to be the second most climatically important volcano of the last 50 years. ${ }^{20}$ Simulations were performed to determine the potential impact on southern Africa for aerosol injections into (1) the northern hemisphere, (2) the southern hemisphere and (3) both hemispheres (see Haywood et al. ${ }^{13}$ for further details). Figures $5 \mathrm{a}$ and $5 \mathrm{~b}$ show the results for December-April rainfall. For this relatively modest eruption, there was a robust drying of $10-50 \mathrm{~mm} /$ month, equivalent to about a $20 \%$ decrease in annual mean rainfall, regardless of whether the injection was in both hemispheres or in one hemisphere only. For an eruption as massive as Tambora $\left(60 \mathrm{MtSO}_{2}\right)$, these model results suggest that the impact across much of the summer rainfall region of southern Africa could have been far more severe, both in terms of the reduction in rainfall and the duration of the impact, which could have been 4 to 5 years following the eruption owing to the longer residence time of aerosol injected to higher regions of the stratosphere.

Of interest is the model result which suggests that the coastal margin of southeastern southern Africa might, even under the extreme conditions created by Tambora, not have been as severely impacted as the interior of the subcontinent. This possibility, in turn, suggests that the more coastal dwelling population may have escaped the worst consequences of the drought, but further multi-model assessments would be needed to assess the robustness of this result.

Nevertheless, the conclusions drawn from the Hadley model results, supported by the tree-ring based SSTs which indicate cooling and drying, suggest that the impact of Tambora on the climate of the region could have significantly exceeded that suggested by the above evidence. It may be added that the methodology employed represents one of the few ways in which climatic aberrations may be illuminated in a location and at a time which has little other supporting material available. ${ }^{17,18}$
Hall ${ }^{21}$, using oral history and the analysis of tree rings, suggested that there were three major changes in climate in southeastern southern Africa during the 18th and 19th centuries: 1700-1750 (dry), late 1700s (wet) and 1800-1820 (dry). The drought in the early part of the 19th century was referred to by the Nguni people as the 'madlathule' (let one eat what he can and say naught) ${ }^{22}$ and is coincident with a serious breakdown of social, political and economic institutions in the region. ${ }^{23}$

The tree-ring work in Zimbabwe ${ }^{10}$ confirms the dry period identified by Hall ${ }^{21}$ in the first two decades of the 19th century (Figure 6) as well as the extended dry period coincident with the eruption of Krakatau (1883) described by Grab and Nash ${ }^{17}$. The rainfall reconstructed from our tree-ring data shown in Figure 6 suggests that the effects of the unknown eruption in 1809, followed by that of Tambora, combined to produce an extended period of 15 years of drought in the southeastern region.

Of the six prolonged drought periods in the reconstructed rainfall record shown in Figure 6, three are associated with volcanism (1809-1823: unknown eruption in 1809 and Tambora in 1815; 1838-1870: Amagura in 1846; 1880-1896: Krakatau in 1883). The drought of the 1920s, which lasted into 1933, is well known for its devastation of farming in Natal but was not associated with any volcanism. ${ }^{24}$

The accumulated evidence cited above suggests that the combined eruptions of the 1809 volcano and Tambora in 1815 created devastating drought and cold conditions in southeastern southern Africa for much of the second decade of the 19th century. These conditions initiated by the 1809 event, became extreme after 1815 and likely extended over much of the summertime rainfall region of southeastern and central southern Africa, reducing rainfall and the growing seasons to less than half of the mean annual values (Figures $5 \mathrm{a}$ and $5 \mathrm{~b}$ ).

Nicholson et al..$^{25}$ show a ubiquitous period of aridity in the earliest years of the 19th century (see Figure 10 in Nicholson et al. ${ }^{25}$ ) based upon a composite precipitation data set compiled for Africa, including the Kalahari, over the last two centuries. Holmgren et al. ${ }^{26}$, using isotopes of oxygen in stalactites from the Limpopo Province of South Africa, show extreme dry conditions (see Figure 4 in Holmgren et al. ${ }^{26}$ ) prevailing at the end of the 18th century.

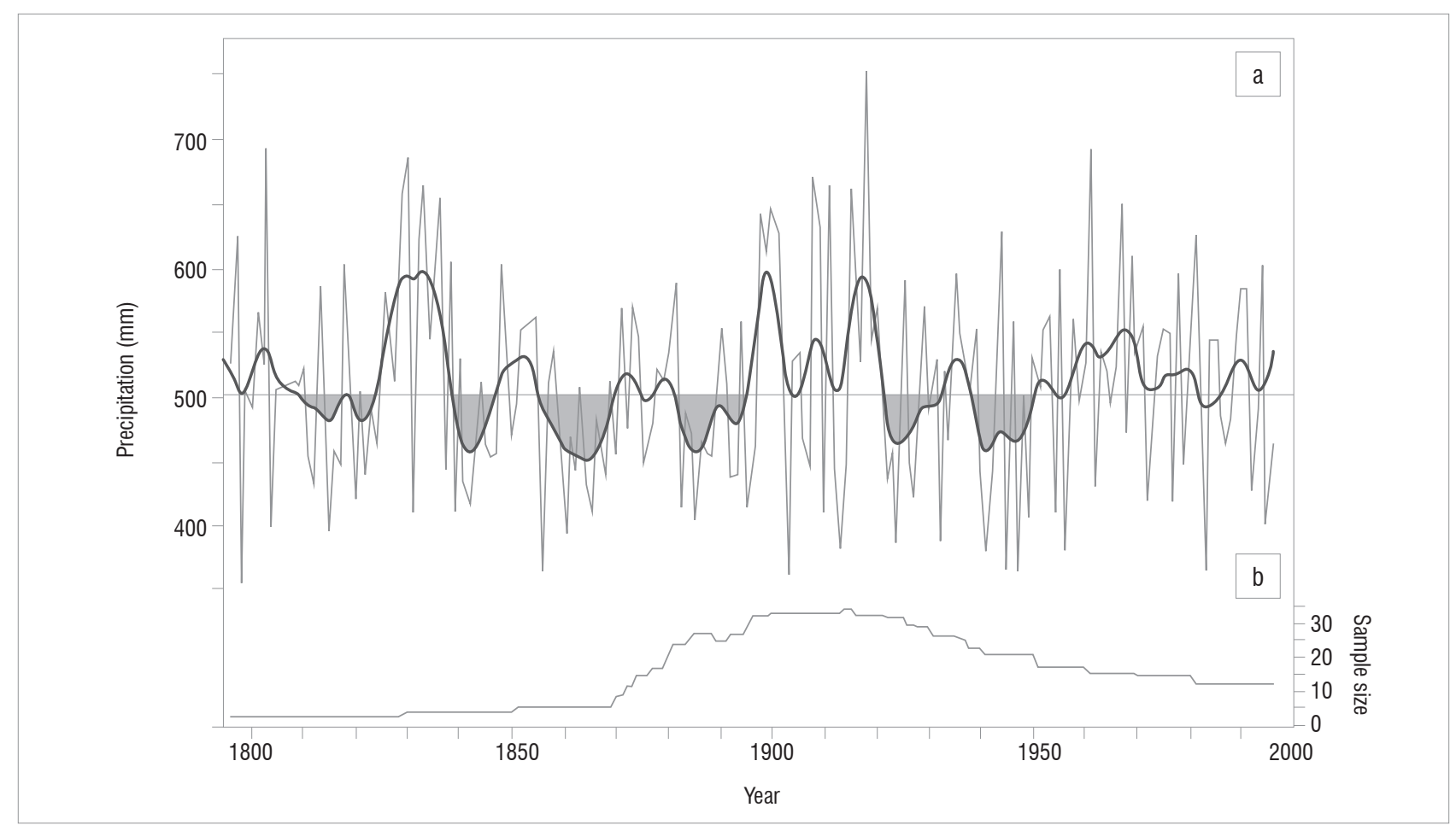

Figure 6: (a) Annual (thin line) and 10-year smoothing spline (heavy line) of reconstructed November-February regional rainfall for Zimbabwe according to tree-ring data from 1796 to 1996. (b) Sample size over time from 21 trees. The shading indicates six major decadal-length dry periods in Zimbabwe during the 19th and 20th centuries. 


\section{Other environmental factors}

Ballard ${ }^{23}$, Guy ${ }^{27}$, Mcl Daniel ${ }^{28}$, Eldredge ${ }^{29}$ and Gump ${ }^{30}$ have all drawn attention to the role played by agricultural practices, soil characteristics and fertility and the carrying capacity of the pastures of the region east and southeast of the Drakensberg towards the Indian Ocean coast. Acocks ${ }^{31}$ reconstruction of vegetation for the above region from the 15 th to the 20th centuries suggests that, over time, good grazing is replaced by poorer species in the wetter regions and not at all in the drier regions. Both Guy ${ }^{27}$ and Gump ${ }^{30}$ argue that significant environmental degeneration had occurred by the end of the 18th century in the Zululand region.

Reduction in carrying capacity progressively limited the time of year and the area available for grazing while the increasing numbers of livestock and people heightened the pressure on these natural resources. By the early 19th century, Wilson ${ }^{32}$ estimated that the number of cattle in the Zululand region likely exceeded the number of people.

Maize may have largely replaced millet and sorghum by the beginning of the 19th century in the Zululand region. Millet and sorghum are drought resistant, grow well in relatively poor sandy soils, require little rain, mature quickly and are suited to short growing seasons. Both crops store well and provide sustenance over multiple seasons. Maize, while possessing some advantages over millet and sorghum such as higher crop yields, has serious relative disadvantages. Maize requires higher rainfall than either millet or sorghum, and requires well-drained soils high in nitrogen, phosphorus and potash. Without supplemental nutrients, maize quickly exhausts soils. Maize is also subject to insect damage while stored.

While cumulatively over time, all of the above factors eventually lead to ecological disequilibrium, such a change is gradual rather than sudden and is spatially inhomogeneous. The exception to such a response could be the result of a sudden occurrence of extreme conditions such as a drought, which could precipitously trigger the simultaneous collapse over a large region.

\section{Summary and conclusions}

The rainfall regime of southern Africa, encompassing most of present day KwaZulu-Natal, the far Eastern Cape, the lowlands of Lesotho and much of the interior plateau, is subject to the large-scale equatorial circulations of the earth's atmosphere. The primary effect of the large-scale circulations upon the rainfall of the region is to impose pervasive dry conditions with a high level of variability. Such variability can take the form of decadal fluctuations in rainfall resulting, alternately, in droughts and floods.

Irregular volcanic activity, occurring particularly in the global equatorial and tropical regions, introduces an anomalous response in rainfall, potentially interfering with the larger-scale rainfall production. The causal relationship between rainfall and the eruption is a cooling effect induced by the injection of particles from the eruption into the stratosphere and a regional cooling of the sea surface.

Dry conditions as a result of the large-scale circulations can be reinforced by a volcanic eruption and can lead to extreme and protracted drought. Reduction in solar insolation reduces surface temperatures. The suppression of rainfall, the absence of clouds and the presence of low humidity result in cold nights with severe frost, reinforcing the already cold conditions. Damage to crops and pasture and the curtailment of the growing season follow.

Such extreme changes in climate brought about by the coincidence of large-scale atmospheric scales of motion and a major global tectonic event, occur within a period of months or less, and over large spatial areas much greater in extent than the above described region.

Observational and model calculations of the impact of a major volcanic eruption support the above time and space characteristics as well as the magnitude of the resulting drought. These characteristics, while amplified by ecological disequilibrium, occur with a suddenness and uniformity over a wide area not associated with a gradual and inhomogeneous environmental degradation. While such an event follows upon and is connected to both antecedent and subsequent conditions, it differs from these 'before' and 'after' states by the uniqueness of its time and space characteristics.

The magnitude and temporal and spatial identity of the change in climate over Zululand and the adjacent regions as a result of the eruption of Tambora constitute a clearly recognisable and unusual state. Historical evidence of such a state, mainly in the form of extremely dry and cold conditions with associated famine and mortality, would support the recognition of these conditions as those described for the 'mfecane'.

Climatic disruptions in the dry tropics of Africa continue into modern times. Loss of life to famine caused by drought occurs from Somalia through the Sahel to the west coast of North Africa. Volcanic eruptions have preceded three of the four driest Sahelian summers during the past 110 years. Hundreds of thousands of people have lost their lives and tens of millions have been displaced by droughts in the subtropics of north Africa. ${ }^{13}$ The lessons of the mfecane remain as important today as they were two centuries ago. The place and role of the mfecane should remain as marking a singular geophysical and human event in the history of southeastern southern Africa.

\section{Acknowledgements}

We thank Prof. Jim Haywood and Dr Andrew Jones of the Hadley Centre of the United Kingdom's Met Office for their assistance in running simulations of volcanic eruptions on the Centre's coupled atmosphere-ocean general circulation model (HadGEM), work supported by the Joint DECC and Defra Integrated Climate Programme, DECC/DEFRA (GA01101). We also thank Prof. Joe Miller for scholarly guidance on the manuscript and Dr David Hondula for preparation of the figures (both at the University of Virginia) and Mary Morris for bibliographic research, and preparation and submission of the manuscript.

\section{Authors' contributions}

M.G. carried out the meteorological and climatological analysis and compilation including initiating the model simulation of the impact of the volcanic eruption on the climate of southern Africa using the United Kingdom's Meteorological Office's coupled ocean-atmosphere model. M.G. also assembled, submitted and served as corresponding author on the paper. A.D.C. initiated the research into the impact on the climate of southeastern southern Africa of the eruption of Tambora in 1815 and contributed to sections on the changes in crops and agriculture and the role of drought on the people and crops of the region. M.T. carried out the tree-ring analyses of rainfall in Zimbabwe and produced the climatological record of the sea surface temperatures for the 10 driest and 10 wettest years over the period 1857-1996.

\section{References}

1. Omer-Cooper JD. The Zulu aftermath: A nineteenth century revolution in Bantu Africa. London and Ibadau: Longman; 1966.

2. Cobbing J. The case against the mfecane. Paper no 144:1984:27. University of the Witwatersrand African Studies Institute Seminar Series. Seminar paper presented in Johannesburg; March 1984.

3. Hobbs JE, Lindesay JA, Bridgman HA, editors. Climates and the southern continents: Present, past and future. West Sussex: John Wiley and Sons; 1998

4. Garstang M, Fitzjarrald DR. Observations of surface to atmosphere interactions in the tropics. New York: Oxford University Press; 1999.

5. Tyson PD. Climatic changes and variability in southern Africa. Cape Town: Oxford University Press; 1986.

6. Kane RP. Periodicities, ENSO effects and trends of some South African rainfall series: An update. S Afr J Sci. 2009;105:199-207.

7. Stuecker MF, Timmerman A, Jin FF, McGregor S, Ren HL. A combination mode of the annual cycle and the El Niño/Southern Oscillation. Nat Geosci. 2013;6:540-544. http://dx.doi.org/10.1038/nge01826

8. Chang P, Zhang R, Hazeleger W, Wen C, Wan X, Ji L, et al. Oceanic link between abrupt changes in the North Atlantic Ocean and the African monsoon. Nat Geosci. 2008;1:444-448. http://dx.doi.org/10.1038/ngeo218 
9. Shanahan TM, Overpeck JT, Anchukaitis KJ, Beck JW, Cole JE, Dettman $\mathrm{DL}$, et al. Atlantic forcing of persistent drought in West Africa. Science. 2009;324:377-380. http://dx.doi.org/10.1126/science.1166352

10. Therrell MD, Stable DW, Ries LP, Shugart HH. Tree-ring reconstructed rainfall variability in Zimbabwe. Clim Dynam. 2006;26:677-685. http://dx.doi. org/10.1007/s00382-005-0108-2

11. Lamb HH. Volcanic dust in the atmosphere: With a chronology and assessment of its meteorological significance. Philos Trans R Soc Lond A. 1970;266:425-533. http://dx.doi.org/10.1098/rsta.1970.0010

12. Bryson R, Goodman BM. Volcanic activity and climatic changes. Science. 1980;207:1041-1044. http://dx.doi.org/10.1126/science.207.4435.1041

13. Haywood JM, Jones A, Bellouin N, Stephenson D. Asymmetric forcing from stratospheric aerosols impacts Sahelian rainfall. Nat Clim Change. 2013;3:660-665. http://dx.doi.org/10.1038/nclimate1857

14. Joseph R, Zeng N. Seasonally modulated tropical drought induced by volcanic aerosol. J Clim. 2011;24:2045-2060. http://dx.doi. org/10.1175/2009JCLI3170.1

15. Timmreck C. Modeling the climatic effects of large explosive volcanic eruptions. WIREs Clim Change. 2012;3:545-564. http://dx.doi.org/10.1002/ wCC.192

16. Oppenheimer C. Climatic, environmental and human consequences of the largest known historic eruption: Tambora volcano (Indonesia) 1815. Prog Phys Geogr. 2003;27:230-259. http://dx.doi.org/10.1191/0309133303pp379ra

17. Grab SW, Nash DJ. Documentary evidence of climate variability during cold seasons in Lesotho, southern Africa 1833-1900. Clim Dynam. 2010;34:473499. http://dx.doi.org/10.1007/s00382-009-0598-4

18. Nash DJ, Grab SW. A sky of brass and burning winds: Documentary evidence of rainfall variability in the Kingdom of Lesotho, Southern Africa, 1824-1900. Clim Change. 2010;101:617-653. http://dx.doi.org/10.1007/s10584-0099707-y

19. Betraud C, Van Ypersele JP, Berger A. Volcanic and solar impacts on climate since 1700. Clim Dynam. 1999;15:355-367. http://dx.doi.org/10.1007/ s003820050287
20. Haywood JM, Jones A, Clarisse L, Bourassa A, Barnes J, Telford P, et al. Observations of the eruption of the Sarychev volcano and simulations using the HadGEM2 climate model. J Geophys Res. 2010;115(D21). http://dx.doi. org/10.1029/2010JD014447

21. Hall M. Dendroclimatology, rainfall and human adaptation in the later iron age of Natal and Zululand. Ann Natal Mus. 1976;22:693-703.

22. Coleman AD, Garstang M. The disputed territory: A cause of the Anglo-Zulu war - Re-examined. Adv Hist Studies. Forthcoming 2014.

23. Ballard C. Drought and economic distress: South Africa in the 1800s. J Interdis Hist. 1986;XVII(2):359-378. http://dx.doi.org/10.2307/204770

24. Arnold P. Tom and Ethel: The story of a soldier settlement. Pietermaritzburg: Pam Arnold; 1990.

25. Nicholson SE, Dezfuli AK, Klotter D. A two-century precipitation dataset for the continent of Africa. Bull Amer Meteor Soc. 2012;93:1219-1231. http:// dx.doi.org/10.1175/BAMS-D-11-00212.1

26. Holmgren $\mathrm{K}$, ÖBerg H. Climate change in southern and eastern Africa during the past millennium and its implications for societal development. Environ Dev Sustain. 2006;8:185-195. http://dx.doi.org/10.1007/s10668-005-5752-5

27. Guy J. Ecological factors in the rise of Shaka and the Zulu Kingdom. In: Marks $\mathrm{S}$, Atmore A, editors. Economy and society in pre-industrial South Africa. London: Longman; 1980. p. 102-119.

28. Mcl Daniel B. A geographical study of pre-Shakan Zululand. S Afr Archeol Bull. 1973;55:23-31.

29. Eldredge EA. Drought, famine and disease in nineteenth-century Lesotho. Afr Econ Hist. 1987;16:51-93.

30. Gump J. Origins of the Zulu Kingdom. The Historian. 1988;50:525-527. http://dx.doi.org/10.1111/j.1540-6563.1988.tb00757.x

31. Acocks PH. Veld types of South Africa. Memoirs of the Botanical Survey of South Africa. 1953;28:13.

32. Wilson M. The Nguni people. In: Oxford history of South Africa. London: Oxford University Press; 1968. p. 107-108. 